\title{
Implementation Concept Of "Learning Style Inventory" David Kolb Based PHP On STMIK Nusa Mandiri
}

\author{
Rino Ramadan \\ STMIK Nusa Mandiri \\ Jakarta, Indonesia \\ rindan.wijaya@gmail.com
}

\begin{abstract}
The concept of "Learning Style Inventory" offered David Kolb is a concept for the assessment in detecting a person's learning style. The learning process is based on the experience of having 5 cycles. 5 of them can be used as a reference for the assessment. David Kolb has created 12 questions that can already be used as a reference in making this assessment. Question by David Kolb create an outline already refers to the cycle of learning from experience. After getting answers to 12 questions before, and then we do the calculation based on a formula created by David Kolb. The formula are consists of 4 score. The first score is CE (Concentrate Experience), then the second score is $\mathrm{AE}$ (Active Experimentation), then the third score is RO (Reflective Observation), and the final score is AC (Abstract conceptualization). The assessment process will do is add any weighting of each question and divided based on each option. Then we add up to 12 about the nominal weighting. Having obtained in total, we then perform the detection process of learning styles based on the concept of learning styles with the reference calculation by analysis David Kolb's learning style. The concept offered David Kolb has many implemented with a variety of versions, this time the writer will try to implement this concept to the programming language PHP along with supporters other programming language. By implementing these concepts based on PHP, then the respondent can conduct the assessment process whenever and wherever. The problems that the authors find in the field are still many people who are still not suitable to use their learning style styles. This is caused by not yet defining the type of their learning style, so mapping learning styles is sometimes difficult to do and not in accordance with the tendency of their learning style. From the research that the writer has tried to do, the results of filling out the questionnaire in the application got a number of results, namely the type of divergent learning style of $39 \%$ ( 85 people), then asymilator at $22 \%$ (48 people) accommodator $19 \%$ (42 people) and converging at $18 \%$ (40 people) out of 215 students who filled out the questionnaire.
\end{abstract}

Keywords - David Kolb, PHP, Inventory of learning styles, Implementation.

\section{INTRODUCTION}

Inventory learning style is the process of assessing the tendency of one's learning style.

According to (Hadi Sukmana, 2017) conclude that:

Analysis of the tendency of learning styles and types of learning styles aims to find out the weaknesses and strengths of a student in the learning process of teaching and absorbing information provided by the teacher in a class so that it can improve learning achievement.
According to (Januhari, 2013) conclude that: A failure is found on the Evaluation report Based Study Program Self-Evaluation of the university, where upon entering a few semesters many students withdrew for various reasons, one reason is because of the inability to follow the learning process. In this study, carried out an inventory of learning styles new faculty and students studying in Bali STIKOM teaching methods Learning Style Inventory, expecting to obtain a dominant learning style characteristics model both for lecturers and students that will allow professors to determine the best way to give lectures 
In its application, the assessment process and the questionnaire process are then assessed on the answers to the questionnaire. One concept is the LSI concept offered by David Kolb, the learning style David Colb consists of 4 types. The first learning style is the learning style "Concentrated Experience" always relying on feelings, then being open and always adapting to any changes. And then the second learning style is "Active Experimental Learning Style" is always active in the experimental process, and has a practical approach, and always appreciates the process of completion. And then the third learning style is "Reflective Observation" this learning styles always rely on patience and objectivity, and assess with heart- heart and always rely on your thoughts and feelings, And then the fourth learning style is, "Conceptualizatin Abstract" learning styles always use the logic and ideas of each feeling, then rely on systematic planning and always developing theories.

Actually many writers carry out such implementations, but still use classified manual systems. And in the calculation process respondents still have to wait for a number of opportunities until the results are delivered, based on this problem, the author tries to make the implementation process in real time. So that each respondent who tries to system, can immediately see the results when finished answering some of these questions.

The authors take decision based on the development of technology, information and communication, which has been located in the community and other publication. Author judge, David Kolb's concept was time to offer a concept that can be disseminated in the internet world. So anyone can do research on learning styles of each without limited space and time.

\section{LITERATURE STUDY}

\section{A. Learning styles}

Research on learning styles is thought to have started in five decades ago (Cassidy, 2004). Based on the results of these studies can be seen that there are several theories and models regarding learning styles and the factors that influence it. (Claxton, 1987) Learning styles divide into four major groups, based on personality, information processing, social interaction, and choice of teaching..

\section{B. Konsep David Kolb}

David Kolb's learning style is one model of learning styles based on the processing of information. David Kolb insists that the orientation of a person in the learning process is affected four trends, namely concrete experience (feeling), reflective observation (watching), abstract conceptualization (thinking), and active experimentation (doing). The fourth study tendency when combined will form four types of learning styles that learning style diverger, assimilator, Converger, and Accommodator (Ghufron, 2012).

\section{PHP(PHP Hypertext Preprocessor)}

PHP is a programming language used to create dynamic websites and web applications. In contrast to HTML that can only display static content, PHP can interact with databases, files and folders, making PHP can display dynamic content of a website. Blog, Online Shop, CMS, Forum, and Social Networking Websites are examples of web applications that can be created by PHP. PHP is a scripting language, not a tag-based language such as HTML. PHP includes cross-platform language, this means that PHP can run on any operating system that is different (Windows, Linux, or Mac). PHP program written in plain text files (plain text) and have the suffix ".php" (Yuliano, 2007).

\section{Entity Relationship Diagram (ERD)}

ERD is a graphical notation in conceptual data modeling that describes the relationship between storage. ERD used to model data structures and relationships among the data, because it is relatively complex. With ERD we can test the model by ignoring the process that must be done (Irmansyah, 2003).

\section{RESEARCH METHODOLOGY}

\section{A. Data collection}

The data collection technique that the author did in making this application was based on research needs at STMIK Nusa Mandiri Jakarta:

- Directly observe the activities of the activity is going on, to get the data are complete and accurate. In this observational method authors direct observation on STMIK Nusa Mandiri in Jakarta to obtain a business process that lets applied in making this application.

- Interview, this activity is carried out by direct conversation, and conducting Question and Answer for STMIK Nusa Mandiri Jakarta students, in order to get complete and relevation with this application.

- Library Studies, using this method helps writers to make reports that are supported by books, journals, internet and references related to the related problems in helping to get this research. 


\section{B. Model System Development}

The research method applied in this research is the development of the waterfall method. Waterfall method is a model of information system development systematic and sequential (Pressman, 2002). Waterfall method has the following stages (Sommerville, 2011) :

\section{Requirements analysis and definition}

System services, obstacles, and results of consultations with approved users and provided as system specifications.

\section{System and software design}

The stages of system design allocate system requirements both hardware and software by making the overall system architecture. Software design is done by the process of designing and drawing basic software systems.

\section{Implementation and unit testing}

At this stage, software design is realized as a series of programs or program units. Tests involve verification that each unit meets its specifications.

\section{Integration and system testing}

Individual program units are combined and issued as a complete system to ascertain whether or not according to software requirements. After evaluation, software can be distributed to customers.

\section{Operation and maintenance}

Usually this stage is the longest stage. System that is installed and used in a real way. Maintenance involves error correction that is not found in the previous stages, improves implementation of the system unit, and improves service systems for new needs.

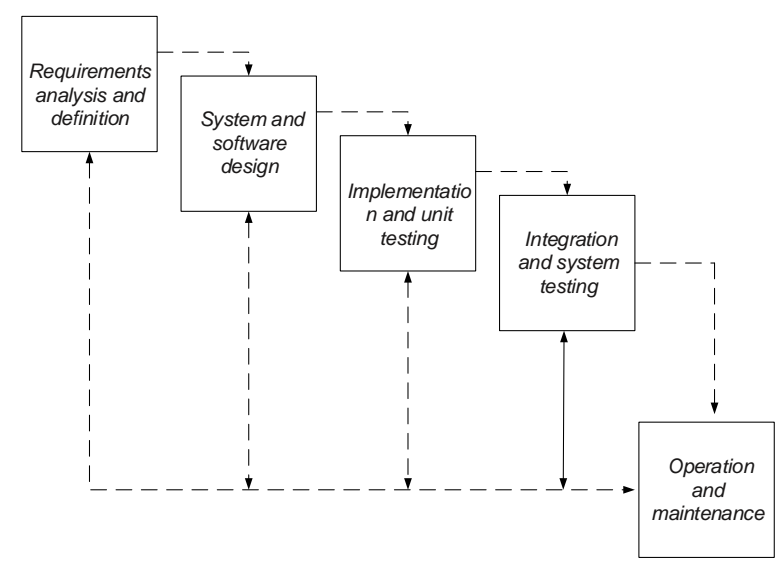

Figure 1. Waterfall Model

Figure 1 is a chart of the waterfall method which is a system development method used in this study.

\section{RESULT AND DISCUSSION}

A. System Analysis

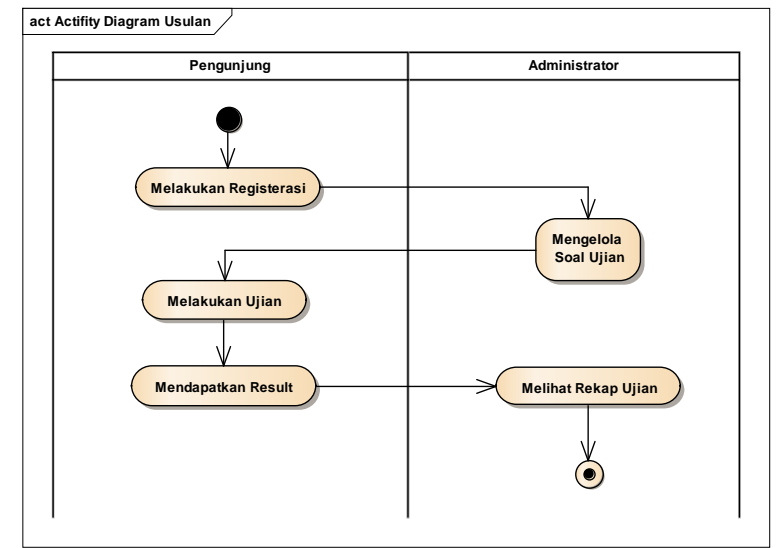

Figure 2. Proposed System Activity Diagram

Implementation of David Kolb's Concept of "Inventory of Learning Styles" Based on PHP at STMIK Nusa Mandiri was made to make it easier for students, lecturers, staff, and interested parties to access information relating to learning styles.

Where they only need to interact with web media browsers to detect their learning styles. The following are the requirements specifications (system requirements) of the Implementation of the David Kolb Concept of "Learning Style Inventory" Based on PHP at STMIK Nusa Mandiri:

Administrator page:

A1. Administrators can log in. 
A2. Administrators can see the main page.

A3. Administrators can view online test recaps.

A4. Administrators can test online.

A5. Administrators can manage questions.

A6. Administrators can log out.

Visitor Page:

B1. Visitors can register.

B2. Visitors can log in.

B3. Visitors can test online.

B4. Visitors can see the main page.

B5. Visitors can see the results of online tests.

B6. Visitors can log out.

\section{B. Use Case Diagram}

To visually describe the interaction between the user and the system intended by the use case diagram as follows.

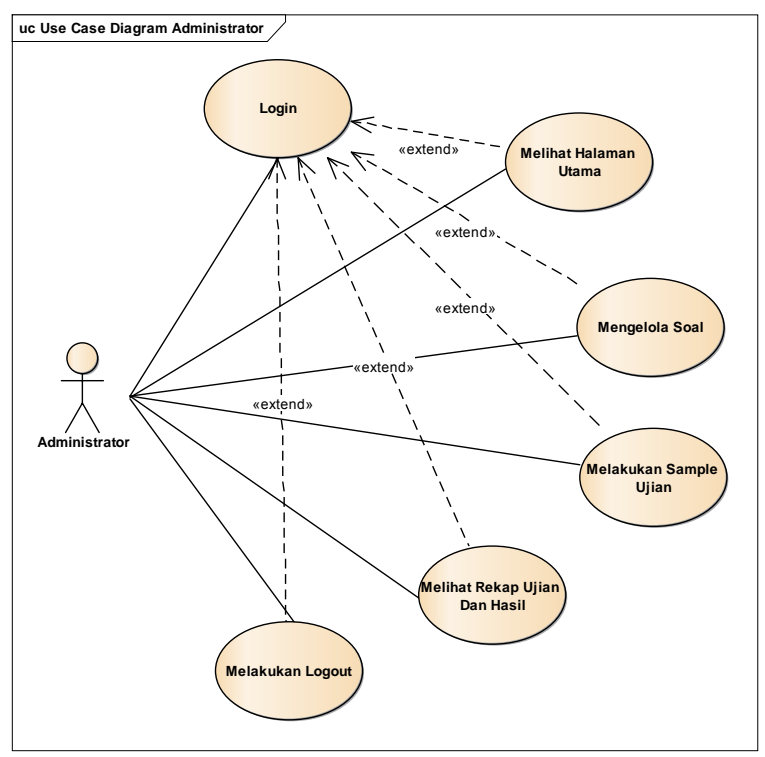

Figure 3. Use Case Diagram Administrator Page

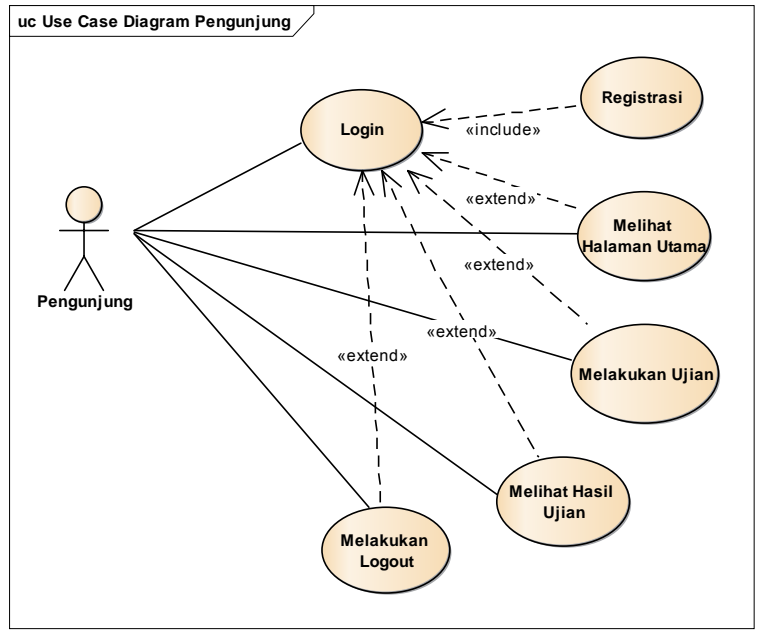

Figure 4. Use Case Diagram Visitors Page 
C. Entity Relationship Diagram

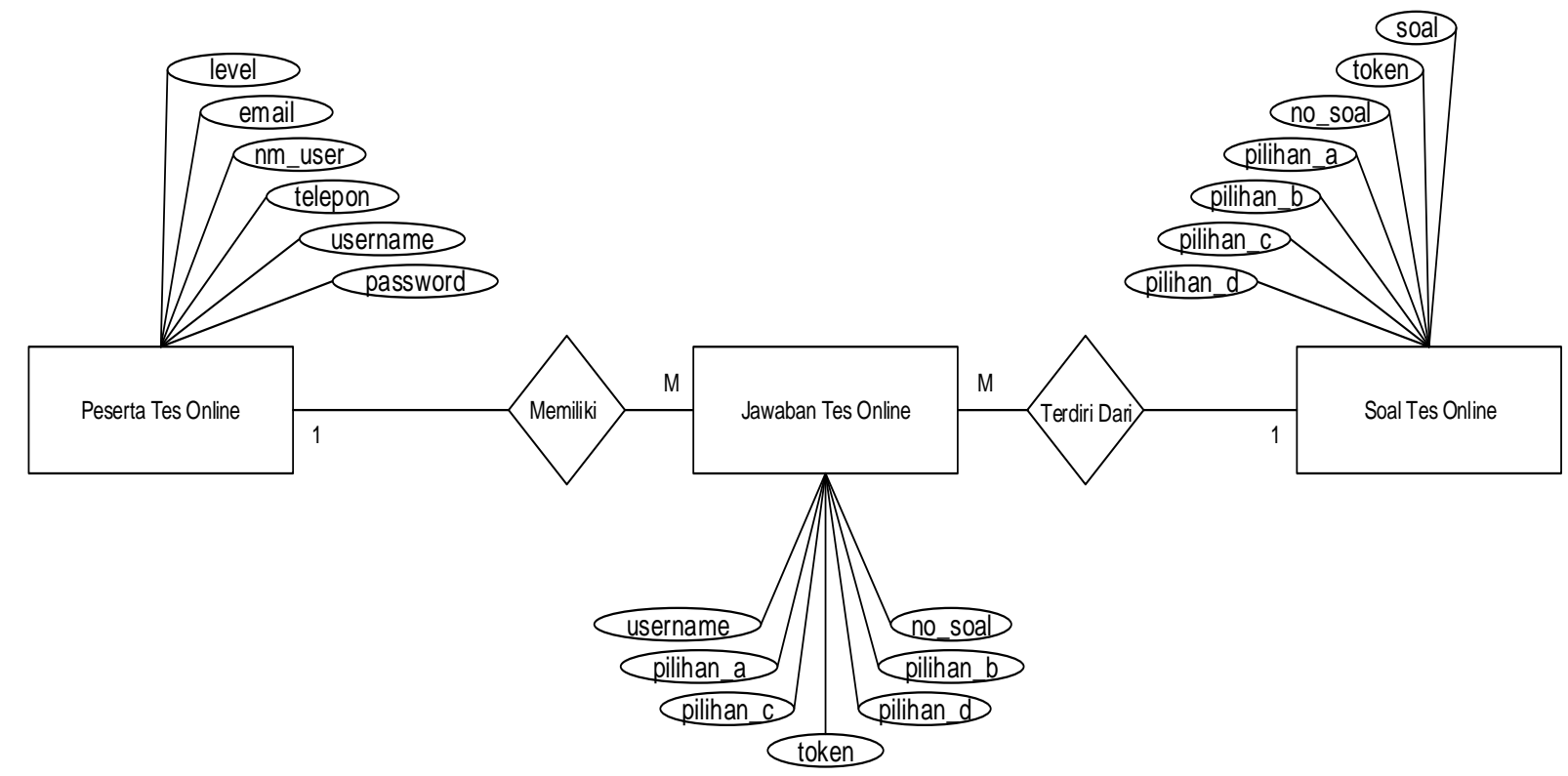

Figure 5. Entity Relationship Diagram

The picture above is the main page. Visitors here can access all information provided by this website starting from viewing the home page, what they say, learning styles, registering and logging in for those who already have a username and password.

D. User Interface

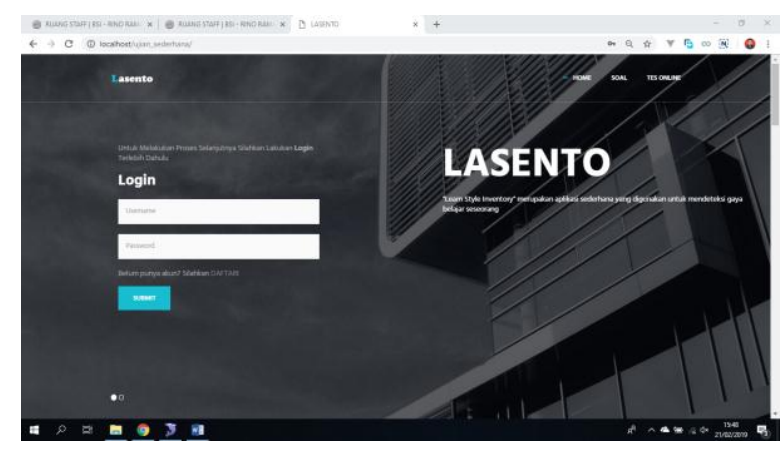

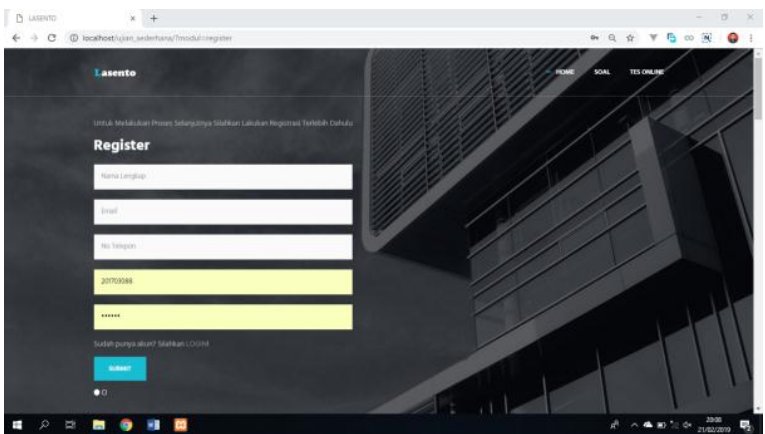

Figure 7. Display Registration Page

The picture above is the user registration page. Registration registrant by inputting data in the form of full name, email, no. telephone, username and password.

Figure 6. Login Display Page 


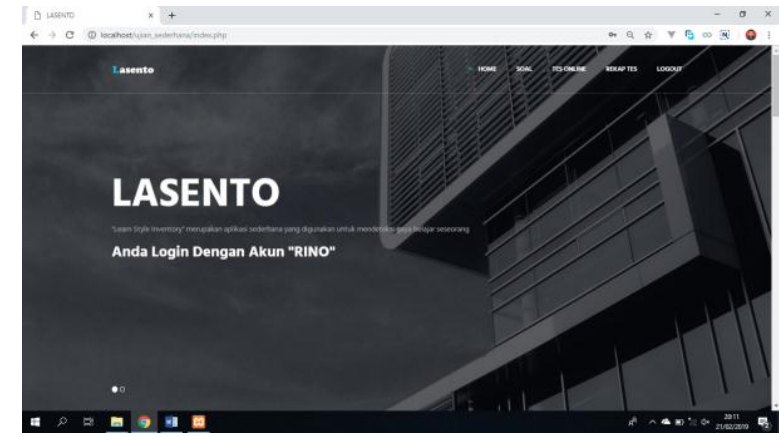

Figure 8. Display of Administrator Pages

The picture above is a page administrator, administrators can process the problem, start adding data, edit data and save data. In addition, administrators can also do sample exams and see the results of the exam, then administrators can see all the exam results of visitors who take the test of learning style.

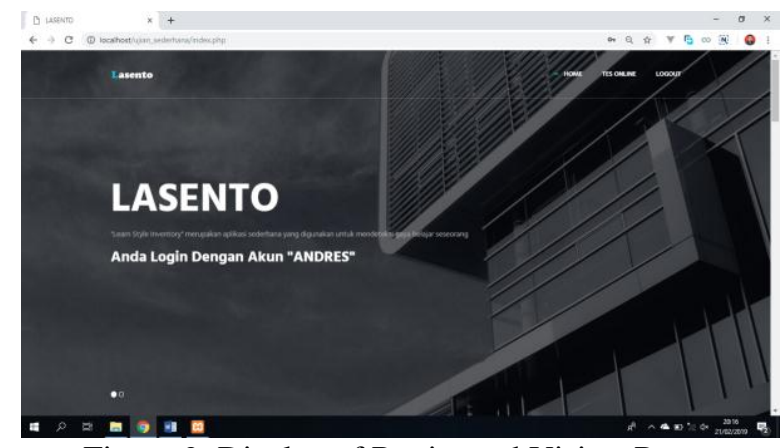

Figure 9. Display of Registered Visitor Pages

The picture above is a menu page for visitors who have registered and logged in. In this page visitors can immediately test the learning style. By doing a test of learning style research. This exam was taken from the process of processing a questionnaire made by David Kolb. And the results are calculated by the system. After the exam is complete, the test results will come out immediately.

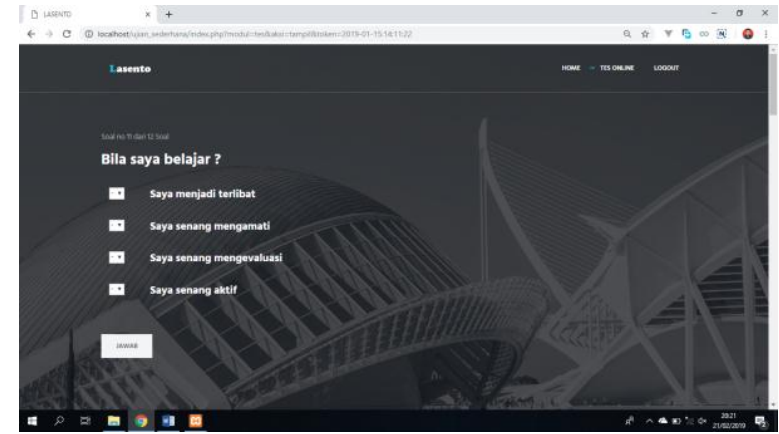

Figure 10. Test Page Display

The picture above is an online learning style research test page, discussion participants about weighting for each available option. Where each option must have a different value.

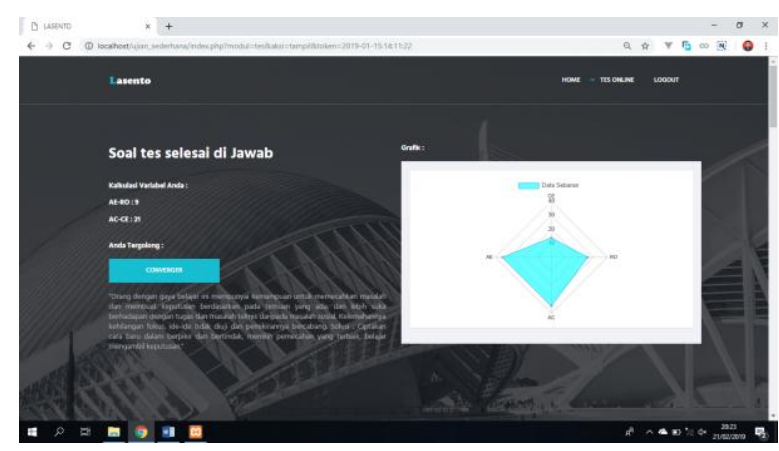

Figure 11. Display of Exam Results Page

The picture above is a page of the results of an online learning style research test, the results of the test describe the class of learning styles related to the resolution of the learning style class and its graphics.

\section{Conclusion}

At the end of this discussion, the author will outline some conclusions obtained through the evaluation results of the results of the publication and after the creation of the website Implementation of the Concept of "Inventory of Learning Styles" David Kolb Based on PHP. Here are some conclusions that the author can take, namely:

1. Implementation of the David Kolb Concept of "Inventory of Learning Styles" Based on PHP, it can make it easier for everyone to process the detection of someone's learning style.

2. By choosing the php platform, everyone can process the detection of any learning style at any time. 


\section{REFERENCES}

Cassidy, S. (2004). Learning Style : An Overview and Measures. Educational Psychology.

Claxton, C. S. dan P. H. M. (1987). Learning Style : Implication for Improving Educational Practices. Washington DC : Association for the Study of Higher Education.

Ghufron, M. N. dan R. R. (2012). Gaya Belajar: Kajian Teoritik. Yogyakarta: Pustaka Pelajar.

Hadi Sukmana, S. (2017). Analisa Kecenderungan Dan Jenis Gaya Belajar Menggunakan Metode Learning Style Inventory (Lsi). Jurnal Pilar Nusa Mandiri, 13(2), 175-180.
Irmansyah, F. (2003). Pengantar Database.

Januhari, N. N. U. (2013). Perancangan Sistem Informasi Learning Style Inventory Berbasis Web pada STIKOM Bali.

Eksplora Informatika, 3(1), 91-100. Retrieved from https://eksplora.stikom-

bali.ac.id/index.php/eksplora/article/view/122/103

Pressman, R. . (2002). Rekayasa Perangkat Lunak: Pendekatan Praktisi(Buku Dua). Yogyakarta: Andi.

Sommerville, I. (2011). Software Engineering 9th Edition. Addison-Wesley.

Yuliano, T. (2007). Pengenalan PHP. 